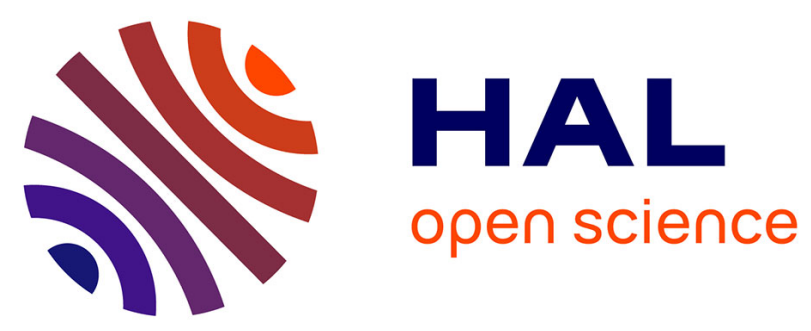

\title{
Use of sperm DNA integrity as a marker for exposure to contamination in Palaemon serratus (Pennant 1777): Intrinsic variability, baseline level and in situ deployment
} Alexandre Erraud, Marc Bonnard, Arnaud Chaumot, Olivier Geffard, Aurelie Duflot, Joëlle Forget-Leray, Frank Le Foll, Alain Geffard, Benoît Xuereb

\section{To cite this version:}

Alexandre Erraud, Marc Bonnard, Arnaud Chaumot, Olivier Geffard, Aurelie Duflot, et al.. Use of sperm DNA integrity as a marker for exposure to contamination in Palaemon serratus (Pennant 1777): Intrinsic variability, baseline level and in situ deployment. Water Research, 2018, 132, pp.124-134. 10.1016/j.watres.2017.12.057 . hal-01917353

\section{HAL Id: hal-01917353 \\ https://hal.science/hal-01917353}

Submitted on 9 Nov 2018

HAL is a multi-disciplinary open access archive for the deposit and dissemination of scientific research documents, whether they are published or not. The documents may come from teaching and research institutions in France or abroad, or from public or private research centers.
L'archive ouverte pluridisciplinaire HAL, est destinée au dépôt et à la diffusion de documents scientifiques de niveau recherche, publiés ou non, émanant des établissements d'enseignement et de recherche français ou étrangers, des laboratoires publics ou privés. 


\section{Accepted Manuscript}

Use of sperm DNA integrity as a marker for exposure to contamination in Palaemon serratus (Pennant 1777): Intrinsic variability, baseline level and in situ deployment

Alexandre Erraud, Marc Bonnard, Arnaud Chaumot, Olivier Geffard, Aurélie Duflot, Joëlle Forget-Leray, Frank Le Foll, Alain Geffard, Benoit Xuereb

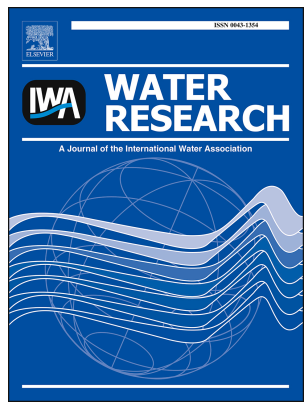

PII:

S0043-1354(17)31052-7

DOI:

10.1016/j.watres.2017.12.057

Reference: WR 13455

To appear in: Water Research

Received Date: 17 July 2017

Revised Date: 22 November 2017

Accepted Date: 22 December 2017

Please cite this article as: Erraud, A., Bonnard, M., Chaumot, A., Geffard, O., Duflot, Auré., ForgetLeray, Joë., Le Foll, F., Geffard, A., Xuereb, B., Use of sperm DNA integrity as a marker for exposure to contamination in Palaemon serratus (Pennant 1777): Intrinsic variability, baseline level and in situ deployment, Water Research (2018), doi: 10.1016/j.watres.2017.12.057.

This is a PDF file of an unedited manuscript that has been accepted for publication. As a service to our customers we are providing this early version of the manuscript. The manuscript will undergo copyediting, typesetting, and review of the resulting proof before it is published in its final form. Please note that during the production process errors may be discovered which could affect the content, and all legal disclaimers that apply to the journal pertain. 


\section{Use of sperm DNA integrity as a marker for exposure to}

2 contamination in Palaemon serratus (Pennant 1777):

3 intrinsic variability, baseline level and in situ deployment.

${ }^{1}$ Normandie Univ, UNIHAVRE, UMR-I 02 SEBIO, FR CNRS 3730 SCALE, 76600 Le Havre, France

${ }^{2}$ Université Reims Champagne Ardenne, UMR-I 02 SEBIO, 51100 Reims, France.

${ }^{3}$ IRSTEA, UR MALY Laboratoire d'écotoxicologie, centre de Lyon-Villeurbanne, F-69616 Villeurbanne, France

* Corresponding author

Email: benoit.xuereb@univ-lehavre.fr

Tel: +33 2328599 11; fax: +3323274 4505

\section{Abstract}

In a previous study, the Comet assay was optimized for Palaemon serratus prawns in order to propose a biomarker for sperm quality in this species. However, better knowledge of its basal level and its natural variability, related to intrinsic biotic and environmental abiotic factors, is required before any relevant use of this biomarker in the field. To fulfill this goal, the present study proceeded in three steps: (i) the temporal variability of DNA integrity was followed monthly in a reference population over a 2-year period, (ii) the correlation between the main intrinsic biotic (i.e. size, weight and molting stage) and abiotic factors (i.e. water temperature) were recorded in the field, and the basal DNA integrity was assessed in order to scrutinize any confounding influence of factors unrelated to toxic response, (iii) the baseline level was used to discriminate biomarker response among different stations displaying contrasting contamination levels. The results of the two-year monitoring in the reference population revealed no correlation between the levels of spermatozoa DNA damage and temperature, body size, weight or molting stage. Only a slight variability between monthly samplings was detected. On the basis of these field-collected data, we defined a reference distribution (i.e. $52.6 \pm 5.6$ A.U) with a threshold value (i.e. 61.7 A.U). Finally, this threshold value proved its relevance to discriminate among stations with contrasting pollution levels around the Seine Bay. Indeed, the results suggest significant DNA damage in populations nearest the Seine estuary, a major source of contaminants in the Bay, and a lower effect in populations further away from the estuary. The overall conclusion was that the Comet assay on P. serratus spermatozoa could be a useful tool for the monitoring of the toxicological print within sperm and main globally the contamination exposure of crustaceans in marine waters.

Key words: Comet assay, Environmental genotoxicity, Biomonitoring, Reference, Threshold value, Crustacean. 
1. Introduction

Pollution released from industrial wastewater, farming, and urban sources is a major threat to organisms living in the aquatic environment. Nowadays, estuarine and marine areas are one of the main preoccupations of aquatic ecotoxicologists; due to their ultimate destination position for most anthropogenic compounds, they are subjected to contamination from point and diffuse sources (Tappin and Millward, 2015). From a toxicological point of view, biocenotic approaches and chemical analyses (e.g. sediment and biota), which are recommended by the Water Framework Directive 2000/60/EC, appear to be limited in their capacity to identify contamination effects on aquatic populations. To address this constraint, the UE Marine Strategy Framework Directive 2008/56/EC introduced the development of biomarkers with the view to their deployment in transitional and coastal waters. Indeed, biomarkers are early-warning tools assessing a causal relationship between the exposure to chemicals and the impacts on organisms, including factors such as bioavailability and mixture effects of known and unknown chemicals (Hanson et al., 2010). Biomarkers should be reliable, robust, easily applicable, only modulated by contaminants, and predictors of adverse impacts on populations and communities. In reality, almost all biomarkers are influenced by abiotic factors such as water temperature, salinity, $\mathrm{pH}$ and dissolved oxygen ( Buschini et al., 2003; Bolognesi et al., 2004; Leinio and Lehtonen, 2005; Pfeifer et al., 2005) or intrinsic variables linked to age, sex or reproductive stage (Jha, 2008; Lacaze et al., 2011a; Sanchez et al., 2008; Sheehan and Power, 1999; Wiklund and Sundelin, 2004; Xuereb et al., 2009). Because of these confounding factors, biomarkers are still not often routinely employed in biomonitoring surveys, particularly in studies on a spatial or temporal large scale. The major part of in situ application with biomarkers is generally based on the comparison between a reference site and an impacted site (e.g. upstream and downstream comparisons) (Flammarion et al., 2002; Flammarion and Garric, 1997). This (i) imposes similar physicochemical conditions between stations in absence of contamination (Underwood, 2000) and (ii) consequently limits the assessment in punctual studies and local areas. Alternatively, some solutions have been proposed to control the influence of both biotic and environmental factors on the response of biomarkers, and make possible their deployment within field surveys on a larger scale. Among them, the assessment of natural variability to propose a basal reference while taking into account a spatiotemporal change has proved its effectiveness (Barrick et al., 2016; Hagger et al., 2008; Hanson et al., 2011; Jubeaux et al., 2012; Lacaze et al., 2011a; Xuereb et al., 2009). This methodology makes it possible to (i) compare sites without a reference site, (ii) reveal the exposure of organisms to one or several contaminants in low contrasted or contaminated situations and (iii) prevent false negatives. For the estimation of such ranges, a monitoring of several reference sites in different seasons is recommended. The 
OSPAR convention in 2013 has recommended that organisms should be collected from reference sites for at

66

67

68

69 least two seasonal cycles to assess the influence of confounding factors (Amiard-Triquet et al. 2015).

Among biomarkers for damage, genotoxicity biomarkers are considered as integrated tools, able to provide complementary information to chemical and ecological analyses for field monitoring (Lacaze et al., 2011a). Indeed, contaminants described as potentially genotoxic would represent one-third of the anthropogenic compounds released into the marine environment (Claxton et al., 1998). Interaction of these compounds on the reproduction process may have an even greater impact at the population level than carcinogenic effects for organisms (Aitken and De Iuliis, 2007). In germ line cells, spermatozoa proved to be sensitive to water contamination because of their inability to prevent oxidative stress and to repair DNA damage. These particularities make them a more integrated cellular model of chemical exposure than oocytes (Aitken et al., 2004; Aitken and Baker, 2006; Lacaze et al., 2010; Lee and Steinert, 2003; Lewis and Galloway, 2009; Santos et al., 2014). Moreover, several authors have already demonstrated the relationship between genotoxicity in sperm and reproductive impairment, in invertebrates (Lacaze et al., 2011a; Lewis \& Galloway., 2009) as well as in fish species (Devaux et al., 2011; Santos et al., 2013ab). These studies highlighted the main interest of including a biomarker of genotoxicity measured in sperm for environmental monitoring and ecological risk assessment. The Comet assay or Single-cell gel electrophoresis assay (SCGE) has become one of the most widely used for detecting DNA strand breaks in aquatic animals (Cotelle and Fe, 1999; Frenzilli et al., 2009; Jha, 2008; Lacaze et al, 2011; Lee and Steinert, 2003; Martins and Costa, 2015; Mitchelmore and Chipman, 1998). Furthermore, Comet assay on spermatozoa for environmental monitoring has been recommended in many reviews (Jha, 2008; Speit et al., 2009; Villani et al., 2010).

As a member of the crustacean family, Palaemonid prawns have been commonly used as a relevant sentinel species for assessing the health conditions of estuaries and coastal systems (Bocquene et al., 1995; Frasco et al., 2008; Key et al., 2006). These species are relatively easy to identify, manipulate and maintain in the laboratory or to use for in situ biosurveys. Palaemon genus is widespread and common in the coastal and estuarine waters of Western Europe, where they are often found in high density (Campillo, 1975). Moreover, these prawns are an important trophic component for many fish and other crustacean species, including commercially valuable ones, and play a major part in the detritus breakdown process, being primary and secondary consumers (Anderson, 1985). A particular interest has recently been attributed to the Palaemon serratus species, which is a coastal species with a large distribution around the European coast (North Sea, English Channel, Atlantic and Mediterranean coast; Campillo, 1975). 
Our work aims to develop the Comet assay on Palaemonid spermatozoa and propose it as a reliable and robust biomarker for the surveys of the European coastal and estuarine water bodies. As recommended by Azqueta and Collins (2013), a preliminary study related to the methodological optimization of the Comet assay protocol was performed in P. serratus (Erraud et al., 2017). This step, which is unavoidable before any deployment in field studies, led us to propose a procedure for collecting a homogeneous population of mature spermatozoa and measuring their DNA integrity. Palaemonid sperm turned out to be sensitive to different genotoxic pathways. Henceforth, the aim of the present study was (i) to develop a procedure to obtain the lowest variability of biomarker response related to intrinsic biotic factors, and (ii) to define reference values of our genotoxicity

103 biomarker taking into account the effect of environmental confounding factors. For that, the inter-individual and

104 seasonal variability of the basal level of sperm DNA damage was investigated during a two-year period within a

105 wild population of prawns in a reference site (i.e. Yport), in order to propose a reference distribution and a

106 threshold value for this biological measurement. In the second step, sperm DNA damage was measured during

107 two campaigns of biomonitoring within populations in different stations of the Seine bay displaying contrasting

108 degrees of contamination, in order to assess the relevance of this reference distribution to discriminate toxic effect.

\section{2. Materials and methods}

\section{2.1. Localisation of studied area}

113 The mouth of the Seine (Normandy, France) is marked by the discharge of a wide diversity of chemical

114 contaminants (i.e. drained by the Seine River), most of which are associated to the particles of the sedimentary

115 plume. The contamination is transported by the longshore drift along the coastline mainly in a northerly direction

116 (Augris et al., 2004), up to the seawall of Antifer Harbor. This 3-kilometer long transverse structure deflects the

117 contaminated plume offshore, creating a sedimentation area upstream of the seawall (i.e. south of Antifer

118 Harbor) (Brivois et al., 2015).

119 The contamination gradients from the Seine estuary toward both the north and the south of the bay are well 120 illustrated by the ROCCH data records (Chemical Contamination Observation Network; 121 http://www.ifremer.fr/envlit/) synthetized in Table 1. This table indicates the annual mean (i.e. 2015 and 2016) 122 of cumulated concentrations of polychlorobiphenyl congeners (i.e. CB138; CB180; CB156; CB28; CB52; 123 CB105; CB153; et le CB101), polycyclic aromatic hydrocarbons (i.e. Benzo(b)fluoranthene; Chrysene; 124 Dibenzo(a,h)anthracene; Fluoranthene; Indeno(1,2,3-cd)pyrene; Anthracene; Phenanthrene; Pyrene; 
Benzo(g,h,i)perylene; Benzo(k)fluoranthene; Benzo(a)pyrene; Benzo(a)anthracene) and seven metals (namely.

Zinc, Cadmium, Copper, Mercury, Silver, Nickel and Lead) measured in soft tissues of mussels sampled from both sides of the mouth of the Seine. A contamination index was calculated to facilitate the appreciation of the contamination level of the different studied ROCCH stations. On the basis of rank transformation according to this equation: $\sum^{n=6}=x i / x \max$ where for each contaminant and each year, $x i=$ annual concentrations of considered stations and $x \max =$ annual concentration maximum, a higher rank (i.e. 1) was accorded to the highest concentration value of PCBs, PAHs and metals for both 2015 and 2016 (Pain-Devin et al., 2014). Then, a global index was obtained by adding rank values for each condition (i.e. contaminant / year).

133 In this context, during the present study, 9 sampling stations were followed in order to investigate different areas

134 of interest along the gradients of contamination (Fig. 1): two stations in the south of the bay (i.e. Longues-sur135 mer and Ver-sur-mer); two close to the mouth of the Seine (i.e. stations of Trouville-sur-mer and Cap de la 136 Hève, in the south and north respectively); five in the north of the bay, downstream (i.e. stations of Octeville-sur137 mer and Southern Antifer) and upstream from the Antifer Harbor (i.e. stations of Northern Antifer, Yport and 138 Senneville-sur-mer).

\subsection{Procedure of prawn sampling}

141 Adult specimens of $P$. serratus were collected on the intertidal rocky shore of the littoral of the Seine Bay using

142 a hand-net. Water temperature, salinity, $\mathrm{pH}$ and dissolved oxygen were systematically recorded. Sexually mature

143 male prawns were immediately shortlisted by the presence of secondary sexual characteristics, as described in

144 Erraud et al. (2017). Prawns were brought to the laboratory in one hour, in 30 L-plastic containers supplied with

145 the natural seawater of the sampling station, under oxygenation. Males were kept in the plastic containers under 146 oxygenation until the analysis of DNA damage from 10 individual sperm suspensions (i.e. $\mathrm{n}=10$ different 147 specimens), the next morning.

\subsection{Procedure of the sperm DNA damage analysis}

150 The measurement of DNA damage in the prawns' spermatozoa was performed according to the methodology

151 described in Erraud et al. (2017). Beforehand, male specimens were weighed and the total cephalothoracic length

152 (LCT) was measured. A fragment of uropod was removed and observed under a photonic microscope (i.e.

153 EVOS ${ }^{\circ}$ FL Auto Cell Imaging System; x100 and then x400) in order to determine the molt stage on the basis of 154 the integumental morphogenesis according to the classification of Drach (1944) (Fig. 2). Spermatophores were 
extracted by a gentle pressure between the fifth pair of pereiopods, allowing the expulsion of spermatophores

156 from the terminal ampullae. Then, spermatophores were transferred into $1.5 \mathrm{~mL}$-microtube, weighed, immersed

157 with $600 \mu \mathrm{L}$ of artificial seawater (adjusted to the hemolymphatic osmolality of P. serratus at i.e. $950-1000$

158 mOsmol. $\mathrm{kg}^{-1}$ ) and ripped by pipetting up and down until the entire laceration of spermatophores. For each

159 specimen tested in the present study, the mortality of sperm-suspension was assessed by a membrane

160 permeability test after mixing cells $1: 1(\mathrm{v} / \mathrm{v})$ with an isotonic Trypan-blue dye solution (i.e. $0.4 \%$ w/v). Cellular

161 mortality was performed in KOVA® slides, using a photonic microscope (x400). Mortality measurements were

162 performed on the spermatozoa suspensions of 20 males. To avoid the measurement of DNA damage due to

163 cytotoxic events leading to an over-estimation, a minimum of ten different males displaying a mortality rate

$164(<15 \%)$ were selected for the assessment of DNA damage using the Comet assay $(n=10)$.

165 Prior to the Comet assay, superfrosted microscope slides were first covered with a normal melting agarose-type I

$166(0.8 \% \mathrm{w} / \mathrm{v})$ in $\mathrm{Ca}^{2+}-\mathrm{Mg}^{2+}$ free PBS (i.e. $10 \mathrm{mM}, \mathrm{pH}$ 7.4) and dried overnight at ambient temperature. After

167 collection of spermatozoa, $60 \mu \mathrm{L}$ of the cell suspension (i.e. $10^{6}$ cells. $\mathrm{mL}^{-1}$ ) were equally mixed with $60 \mu \mathrm{L}$ of

$1681 \%$ low-melting-point agarose-type VII in $\mathrm{Ca}^{2+}-\mathrm{Mg}^{2+}$ free PBS (i.e. $10 \mathrm{mM}, \mathrm{pH} 7.4,37^{\circ} \mathrm{C}-0.5 \%$ final agarose

169 concentration), and immediately deposited onto the coated slides and finally covered with a $24 \times 60 \mathrm{~mm}$

170 coverslip. From this point, all steps of the Comet assay protocol were performed in darkness with inactinic light

171 to prevent additional DNA damage. Slides were cooled for $10 \mathrm{~min}$ at $4^{\circ} \mathrm{C}$ on ice for solidification of agarose.

172 After removal of the coverslip, slides were placed in a freshly prepared lysing solution (i.e. $2.5 \mathrm{M} \mathrm{NaCl}, 100 \mathrm{mM}$

$173 \mathrm{Na}_{2} \mathrm{EDTA}, 10 \mathrm{mM}$ Tris, $1 \%$ Triton X-100 and $10 \%$ DMSO added immediately before use, $\mathrm{pH} 10$ ) at $4{ }^{\circ} \mathrm{C}$ in the

174 dark for 1 hour. After cell lysis, slides were gently placed in a horizontal electrophoresis chamber filled with

175 freshly prepared alkaline solution (i.e. $300 \mathrm{mM} \mathrm{NaOH}, 1 \mathrm{mM} \mathrm{Na} \mathrm{a}_{2} \mathrm{EDTA}, \mathrm{pH}>13$ ). DNA was then allowed to

176 unwind for 15 min. Electrophoresis of DNA was performed in a standard Comet Assay Tank (i.e. 20 slides; 1050

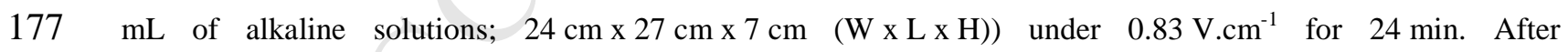

178 electrophoresis, slides were washed in a neutralization buffer (i.e. $0.4 \mathrm{M}$ Tris- $\mathrm{HCl}, \mathrm{pH} 7.5$ ) at $4^{\circ} \mathrm{C}$ for $20 \mathrm{~min}$.

179 The last step consisted of a dehydration of slides in absolute ethanol for $15 \mathrm{~min}$. DNA embedded in the slide was

180 stained with $30 \mu \mathrm{L}$ of a DAPI solution at a concentration of $2 \mu \mathrm{g} \cdot \mathrm{mL}^{-1}$. Slides were blindly observed using an

181 epifluorescence-reversed microscope (Eclipse TE2000-U, Nikon ${ }^{\circledR}$ ). Slide scoring was assessed by a visual

182 scoring according to the method of Collins (2004) which was demonstrated as trustworthy as image analysis

183 (e.g. Azqueta et al., 2011), and proved to be appropriate to detect DNA damage in sperm from P.serratus

184 (Erraud et al. 2017). A minimum of 150 spermatozoa per slide was counted and classified into five categories of 
Comet according to the degree of DNA damage, from 0 (i.e. no tail) to 4 (i.e. almost all DNA in the tail indicating highly damaged DNA). The DNA damage level was expressed in arbitrary units (i.e. AU) (Fig. 3). This arbitrary unit, graduated from 0 to 400 , was calculated by applying the following formula: (percentage of nucleoids in class $0 \times 0)+($ percentage of nucleoids in class $1 \times 1)+($ percentage of nucleoids in class $2 \times 2)+$ (percentage of nucleoids in class $3 \times 3)+($ percentage of nucleoids in class $4 \times 4$ )

\subsection{Characterization of a DNA damage baseline level in prawns from a reference station}

191 In order to describe the natural variability of DNA damage in spermatozoa of $P$. serratus and to define a baseline 192 level, prawns were sampled monthly at the station at Yport, from May to November during two years: 2015 and

1932016 (see section 2.1). Yport, which is located north of Antifer harbor (Fig. 1), is admitted to be a slightly 194 polluted station according to ROCCH data records (see section 2.1) and is used as a reference station in our 195 laboratory (e.g. Rioult et al., 2014). The period from May to November corresponds to the period during which

196 P. serratus specimens are found on the rocky shore of the intertidal zone until they return to greater depths

197 (Campillo, 1975). Prawns were considered and analyzed as previously described (see section 2.3).

\subsection{Biomonitoring of natural populations along the Seine Bay coastline}

199 All stations previously described (see section 2.1; Fig. 1) were monitored during the autumns of 2015 and 2016 200 between mid-September and mid-October, except for Longues-sur-mer and Northern Antifer, which were added 201 during the campaign of 2016. All of these sampling sites exhibited different levels of anthropogenic pressure 202 according to ROCCH observations. Prawns were sampled in the intertidal zone (see section 2.2), except for the 203 stations at Ver-sur-mer and Longues-sur-mer, where prawns were caught by a fisherman using prawn traps close 204 to the coast. Prawns were considered and analysed as previously described (see sections 2.2 and 2.3).

\subsection{Statistical analysis}

207 Statistical analyses were performed with the R studio software v0.99.903 (RStudio Inc.). For values of DNA 208 damage for Yport, normality and homoscedasticity were assessed by a Shapiro-Wilk test and a Bartlett test 209 respectively. Inter-individual variability of DNA damage for each month was then assessed using ANOVA test. 210 The influences of temperature, total weight and total cephalothoracic length on the natural variability of DNA 211 damages were assessed using mixed effect models including sampling date as random effect to take into account 212 pseudo-replication in the dataset. The relationship between DNA damage and the molt stage was assessed using 213 an ANOVA test. A maximum reference threshold for DNA damage of monthly means was defined on the basis 
214 of the variation in the mean of values measured on 10 prawns simultaneously collected from the reference station

215 at a common date $\left(95^{\text {th }}\right.$ percentile). This threshold value of DNA damage was used thereafter for the passive

216 monitoring experiment in order to test whether the mean of recorded values (also 10 prawns per site) conform to

217 this reference distribution. A comparison was also made between the two years at each site using an ANOVA

218 test followed by a post hoc test Tukey HSD.

\section{3. Results}

\subsection{The range of natural variability of spermatozoa DNA damage and definition of a reference distribution}

222 Figure 4 shows the level of DNA damage measured in the spermatozoa of Yport's prawn population (i.e. reference population) from May to November in 2015 and May to October 2016. In November 2016, prawns had already migrated from the intertidal zone. Water temperature, salinity, $\mathrm{pH}$ and dissolved oxygen were recorded monthly throughout the sampling campaigns. No variability of $\mathrm{pH}$ (i.e. $8.21 \pm 0.9$, mean $\pm \mathrm{SD}$ ), salinity (i.e. 33 35 PSU) and dissolved oxygen (i.e. $8.09 \pm 0.24 \mathrm{ppm}$, mean $\pm \mathrm{SD}$ ) was observed during the monitoring. The temperature was the only registered physicochemical factor displaying a seasonal cycle with remarkable variations ranging from 11.8 to $19.2^{\circ} \mathrm{C}$.

229 DNA damage was measured for 7 months in 2015 and again for 6 months in 2016 (10 prawns per sampling date). DNA damage values $(\mathrm{n}=130$ prawns) were normally distributed (Shapiro-Wilk test, $p=0.0632)$ and homoscedasticity among sampling dates was verified (Bartlett test, $p=0.0923$ ). A weak but significant variability of DNA damage levels was detected between sampling dates (ANOVA test, $p=0.0206$ ). However, the DNA damage level of spermatozoa measured in prawns from Yport presented no variability trends. Potential

234 relationships between DNA damage and temperature or intrinsic factors were thus investigated. Figure 5A shows

235 the relationship between the average level of DNA damage in spermatozoa of the 10 prawns of each month and 236 the temperature recorded monthly in the field. No correlation has been observed (Pearson's correlation test, $\mathrm{p}=$ $2370.2926 ; r=0.09)$. The weight and the total cephalothoracic length recorded during the sampling of prawns from 238 the intertidal zone ranged from 7 to $33 \mathrm{~mm}$ and from 420 to $2380 \mathrm{mg}$, respectively. Figure 5BC represents the 239 relationship between DNA damage of 130 prawns and their weight or total cephalothoracic length. No 240 significant influence of these biotic factors with DNA damage level has been observed in mixed effect models $(p$ $241=0.2644$ for the cephalothoracic length; $p=0.4276$ for the weight). Finally, the relationship between the molt 242 stages and DNA damage of spermatozoa obtained on the 130 prawns was assessed (Fig. 6). Sampled prawns 243 were found in all molting stages with a frequency of $2.6 \%$ in stage A, $28.2 \%$ in stage B, $19.6 \%$ in stage C, 20.5 
\% in stage D0, $12.8 \%$ in stage D1', 4,3\% in stage D1", $7.7 \%$ in stage D1'”, and $4.3 \%$ in stage D2. No significant difference was obtained (ANOVA test, $p=0.321$ ). Hence, based on this chronological data set, a reference distribution was established. The mean baseline level was established at 52.6 \pm 5.6 A.U and the upper 95\% unilateral confidence threshold was 61.7 A.U. This maximum damage threshold is based on the variation of the monthly mean of DNA damage levels ( $n=10$ prawns), which notably presented a quite small variability over all months (Variation Coefficient - VC $=10.6 \%$ ). All the mean monthly values of DNA damage recorded during the two-year monitoring in Yport fall below the defined 95\% unilateral confidence threshold (Fig. 4).

\subsection{Measure of DNA damage in sperm from prawns sampled in different populations along the Seine Bay}

The environmental factors were in the previously observed range of the monthly sampling from May to November 2015-16 in Yport (i.e. temperature: $13.8-19.2^{\circ} \mathrm{C}$; Salinity: $33-35$; $\mathrm{pH}: 8.17 \pm 0.5$ and dissolved $\mathrm{O}_{2}$ : $7.95 \pm 0.15 \mathrm{ppm})$. The cephalothoracic size and total weight of prawns sampled along the rocky shore using a hand net (see section 2.1) ranged from 13 to $33 \mathrm{~mm}$ and 525 to $2197 \mathrm{mg}$, respectively. In contrast, prawns sampled by the fisherman at the stations of Ver-sur-mer and Longues-sur-mer displayed slightly bigger size and higher weight (i.e. total weight: $1672-2851 \mathrm{mg}$ and LCT: $26-34 \mathrm{~mm}$ ). Figure 7 presents the passive biomonitoring performed on 7 sites in October 2015 and 9 sites in October 2016 on the Seine Bay to assess the level of DNA damage. Levels of DNA damage displayed no significant variation between 2015 and 2016 in the different sites (HSD Tukey, $p$ > 0.05). All the sites situated north of the Antifer seawall and south of the Seine Estuary presented mean DNA damage levels below the maximum damage threshold of $61.7 \mathrm{AU}$ defined in the reference population (see section 3.1). In contrast, the highest levels of DNA damage were observed in the north

264 of the Seine Bay at the stations of Southern Antifer, Octeville-sur-mer and Cap de la Hève, displaying a maximum of $90.2 \pm 13.8$ A.U, $81.0 \pm 13.3$ A.U and $85.0 \pm 15.8$ A.U, respectively. A significant decrease of 54 $\%$ of the mean level of DNA damage was observed in 2016 between the south and the north of the seawall of Antifer (i.e. $90.2 \pm 13.8$ A.U and $58.4 \pm 27.0$ A.U respectively) (ANOVA, $p=0.0327$ ). However, it can be underlined that the prawns of the northern station showed a significant inter-individual variability $(\mathrm{VC}=46.2 \%)$.

\section{Discussion}

272 Initially, biomarkers were developed in ecotoxicology to assess environmental quality (McCarthy \& Shugart, 273 1990). Even so, they are still rarely used in biomonitoring programs especially in spatial and temporal large- 
274 scale studies due to the lack of control of their natural variability. This natural variability caused by 275 environmental or intrinsic biotic factors other than contaminants can represent a real problem in the 276 identification of the effects of contamination. The only alternative to improve biomarker interpretation is to understand both the natural inter-individual variability, the seasonal variability and the influence of other 278 potential confounding factors from populations of reference sites, in order to establish reference values taking into account this variability (Coulaud et al., 2011; Jemec et al., 2010; Xuereb et al. 2009). When the analysis of the chronological and/or spatial data set displays a non-significant variability for a biomarker under parameters other than the contaminant, a baseline can be constructed directly. However, many biomarkers have shown a marked seasonal variability (Dixon et al., 2002; Jha, 2008; Sanchez et al., 2008; Wiklund and Sundelin, 2004; Barrick et al., 2016). If the results are predominantly affected, the origins of the variability have to be identified and integrated to minimize the risk of misinterpretation. (Wirzinger et al., 2007). The variability can then be minimized by sampling methodology optimizations such as the selection of a standard range of organisms (Xuereb et al. 2009) or about sampling periods (Akcha et al. 2004). In another way, when trends clearly appear, the variability can be directly lessened during the data analysis by using mathematic models (Coulaud et al. 2011; Barrick et al., 2016). Conversely, if the biological response shows stochastic fluctuations, it consequently has no potential to be used in the field (Jubeaux et al., 2012).

The aim of the present study was the assessment of the natural variability of DNA damage on $P$. serratus spermatozoa to propose a reference value distribution allowing the use of this response as biomarkers of genotoxicity in the field. The final step of this process aimed to assess the discriminant power of the biomarker throughout regionally contrasting contaminated stations.

\subsection{Characterization of the natural variability and definition of a baseline level}

296 In the present study, the inter-individual and seasonal variability of the sperm DNA damage basal level was assessed during a two-year period (from May to November in 2015 and 2016) within a reference wild population of P. serratus, Yport. Prawns displayed relatively low damage levels (i.e. 53 A.U. in mean). A residual but significant variation (i.e. VC of the monthly means $=11 \%$ ) of the response has been characterized at the outcome of the data analysis. Our results are consistent with the ones reported by Lacaze et al. (2011b) in spermatozoa of the freshwater shrimp Gammarus fossarum. Their work showed no difference of sperm DNA damage levels in gammarids collected monthly in two reference stations from January to December 2009 and 
levels in different cellular types (i.e. hemolymph cells, and gill cells) in molluscs such as Mytilus sp and fish such as Limanda limanda (Akcha et al., 2004; Dévier et al., 2013; Frenzilli et al., 2001; Magni et al., 2006; Pisanelli et al., 2009; Shaw et al., 2000).

The diagnosis of a residual variation led us to examine the influence of different environmental or intrinsic biotic factors in order to identify potential tendencies which could be diminished by mathematical models or avoided by refining the sampling strategy. Contrary to the continental and estuarine environment, coastal and marine areas appear much buffered in terms of salinity and $\mathrm{pH}$. In the scale of the Seine Bay, variations of these parameters are mostly induced in the winter, where desalinated water provided by the Seine flood is tackled to the coast, decreasing the salinity slightly to a level of 30 in the internal area between the Cap line of Antifer and Ouistreham and all the coasts of the Bay to less than 33. However, the period of coastal presence of prawns (i.e. from May to November) coincides with the period of stability of these parameters in the Seine Bay. On the local scale of a rocky shore, it may have variations in relation to the tidal rhythm (i.e. desiccation and fresh water resurgence). However, during our monitoring, the water temperature was the only measured environmental factor which displayed remarkable seasonal fluctuation (i.e. from 11.8 to $19.2^{\circ} \mathrm{C}$ ). In spite of this contrast, the statistical analysis showed no significant correlation between the water temperature and the measured DNA damage in prawn spermatozoa. Several studies have however demonstrated that the extremities of environmental temperature gradient seem to affect the DNA integrity in different taxa and cell types. Indeed, an increase of the baseline level of DNA damage was observed in erythrocytes of the dab Limanda limanda (Akcha et al. 2004), in cells from the gills, kidney, liver and blood of the mullet Liza aurata (Oliveira et al., 2010) and in haemocytes of the mussel Mytilus galloprovincialis (Pisanelli et al. 2009) during the coldest months of the year. An inverse tendency was also reported for hot summer temperatures such as in the digestive gland cells and gill cells of Mytilus sp (Shaw et al. 2000; Magni et al. 2006) or in gill cells of Dreisseina polymorpha (Michel et al., 2013) and in blood cells of two species of fish, the gray mullet and the sea catfish (De Andrade et al., 2004). Conversely, Lacaze et al. (2011b) recorded no effect of water temperature on DNA integrity of spermatozoa of Gammarids during a laboratory-controlled experimentation (i.e. from 6 to $24{ }^{\circ} \mathrm{C}$ ) as well as in the field (i.e. from 5 to $19{ }^{\circ} \mathrm{C}$ ) except for the month of July in their reference river where a significant increase in DNA damage was measured. In this last case, this increase was explained by a global stress with a temperature exceeding the optimal living temperature (i.e. $>24^{\circ} \mathrm{C}$ for 3 days) and the minimal flow rates which could be associated with a decrease of the oxygen concentration. 
Among the intrinsic biotic factors capable of influencing the baseline level of DNA damage, the age or the life stage was already highlighted in previous works. For example, Akcha et al. (2003) demonstrated that DNA damage measured in blood cells of adult dabs was higher than that in juveniles. A positive correlation between the DNA damage in blood cells and the size was observed in the three-spined stickleback Gasterosteus aculeatus (Wirzinger et al., 2007). Nevertheless, these authors did not exclude a possible effect of chemical stress due to the contamination in their reference station. That has been confirmed by Santos et al. (2014), who demonstrated in the same biological model that there is no correlation between fish length and the level of DNA damage in a reference site. The positive influence of age on DNA damage was also observed in the gill cells and haemocytes of blue mussels (Rank et al., 2005). The authors explained this difference by a higher biotransformation capacity of adults in comparison with juveniles. During the present study, the analysis of the

343 distribution of the prawn cephalothorax size on the basis of work by Campillo (1975) (i.e. concerning the description of cohorts within P. serratus populations of Roscoff, a station located on the French Coast of the English Chanel; 1975), showed that more than $94 \%$ of sampled specimens corresponded to the age class 0 (LCT $<27 \mathrm{~mm}$ ), while only $6 \%$ seem to belong to the age class $1(27<\mathrm{LCT}<36 \mathrm{~mm})$ and none represented the age class $2(\mathrm{LCT} \geq 36 \mathrm{~mm})$. This estimation suggests that the employed capture procedure (i.e. manual capture using a hand-net on intertidal rocky shore) led to a homogenous sampling in terms of the age of prawns.

349 Despite the lack of variability in terms of age, the high level of disparity in terms of size and weight in the age 350 class 0 made us wonder about the potential interaction between the DNA damage in spermatozoa and these two 351 intrinsic biotic parameters. Our results show no significant correlation for total cephalothoracic length and total weights ranging from 7 to $33 \mathrm{~mm}$ and from 420 to $2380 \mathrm{mg}$, respectively.

353 In palaemonids, as for most decapods, sperm resides in the male seminal vesicle in the form of spermatophore 354 (i.e. a medial mucus mass encapsulated in a non-cellular envelope). This particularity offers the advantage to 355 collect and to work only on homogeneous mature spermatozoa populations and therefore to avoid a potential 356 difference in the sensitivity between the different stages of spermatogenesis depending if cells have been 357 exposed during their differentiation or in a mature stage (i.e. as suggested in G. fossarum by Lacaze et al., 358 2011b). However, males being continuously ready to mate, even outside of the reproduction periods (i.e. from 359 November to May in P. serratus; according to Campillo, 1975), the issue of the aging of spermatozoa contained 360 in the spermatophores can legitimately be addressed. Parnes et al. (2006) reported the first evidence that the 361 reproductive cycle of male prawns is strictly associated with their molt cycle in Litopenaeus vannamei, intact 362 spermatophores disappearing about $12 \mathrm{~h}$ premolt and a new pair appearing in the ejaculatory bulbs the day after 
exuviation. Consequently, the different molt stages were used here as chronological markers to assess the influence of retention time of spermatozoa in the spermatophore on their DNA integrity. No significant effect was observed. On the basis of the work of Richard (1978) relative to molt cycle duration in P. serratus and considering prawns sampled in this present work, these results suggested that the spermatozoa could be kept more than one month in the spermatophores without any DNA degradation.

368 Ultimately, a low residual variability of the sperm baseline level of DNA damage was observed, which does not 369 seem to be explained by the environmental or intrinsic factors identified as the most important. Consequently, a 370 reference value was generated from the Yport chronological data set with a mean value of DNA damage of 52.6 $371 \pm 5.6$ A.U and a maximum threshold corresponding to the unilateral $95 \%$ confidence intervals of 61.7 A.U from 372 which a superior DNA damage level could be interpreted as a modulation, resulting from an exposure to 373 contaminants. However, this methodology was developed from only one reference station on prawns of the age 374 class 0 and on the water temperature conditions of spring and summer (i.e. from 11.8 to $19.2{ }^{\circ} \mathrm{C}$ ). As 375 recommended by OSPAR Convention (2013), further studies should investigate several reference stations on a 376 larger range of physicochemical parameters in order to consolidate the robustness of this reference distribution in 377 view to a large-scale deployment.

4.2 Relevance of DNA damage in sperm of prawns in the spatial discrimination of the genotoxicity in different sites of the Seine Bay

The Seine Bay is considered to be one of those most affected by trace metals, PAHs and polychlorinated 382 biphenyls (PCBs) in Europe, presenting a well-defined gradient of contamination which reduces from the mouth 383 of the estuary towards the extremities of the Bay. In order to assess the relevance of the use of a reference 384 distribution presently proposed, different stations were investigated along the Seine Bay coastline. Globally, the 385 results of this work revealed contrasting genotoxic impregnation levels coherent with the contamination gradient 386 of the Seine Bay (i.e. on the basis of mussel bioaccumulation measurements; Tab. 1).

387 Considering the slightly contaminated stations located at the extremity of the bay (i.e. Senneville-sur-Fécamp in 388 the north, and Longues-sur-mer and Ver-sur-mer in the south), the levels of sperm DNA damage were below the 389 maximum threshold (i.e. previously defined by the data set recorded at the station of Yport). These results 390 demonstrate in hindsight the spatial robustness of this reference distribution. Otherwise, the incidence of age 391 class of prawns on levels of sperm DNA damage may be questioned in our study, since the prawns from Ver-sur392 mer and Longues-sur-mer sampled in deeper water by a fisherman, displayed a frequency of age class 1 (i.e. 90 
$\%$ and $100 \%$ on average, respectively) that was higher than those observed during the samplings performed at

394 Yport (i.e. $6 \%$ on average). The results tend to confirm that the age class of prawns has no incidence on sperm

395 DNA integrity. They suggest also that different sampling methods (i.e. hand net and prawn trap) can be used to

396 monitor this biomarker in Palaemonids prawns.

397 Regarding the stations under the influence of the Seine plume, all the stations in the north between the mouth of

398 the estuary and the Antifer Seawall (i.e. Cap de la Hève, Octeville-sur-mer; Southern Antifer) presented

399 significant levels of DNA damage ranging from 31 to $46 \%$ above the maximum threshold. Remarkably, a

400 drastic decrease of DNA damage from the southern to the northern Antifer Seawall was observed despite a

401 spacing of only 1.2 kilometers, highlighting the pronounced effect of the seawall on the drift of the chemical

402 toxic load associated to the Seine plume. In the south, Trouville-sur-mer displayed a surprisingly low level of

403 DNA damage in clear opposition to the stations placed near the mouth of the Seine estuary in the north (i.e. Cap

404 de la Hève). It can be noted for this station that no significant DNA damage level was reported, despite a strong

405 contamination index recorded in the ROCCH station of Villerville (i.e. stations only spaced $6.5 \mathrm{Km}$ apart). It can

406 be rationally hypothesized that, in spite of the proximity of these two stations, Trouville-sur-mer has been less

407 exposed to the Seine plume (i.e. transported along the northern coastline by the longshore drift) than Villerville,

408 which is located nearest the estuary mouth (Fig 1). In the same way, similar genotoxic impacts were observed

409 from Cap de la Hève to Southern Antifer in spite of a halving of the contamination index between these two

410 stations. This gap could be explained by the difference of the contaminant bioavailable fraction between mussels

411 and prawns or by the fact that the most conventional contaminants reported in the survey network do not explain

412 all the genotoxic impact. This report shows the interest of biological monitoring, highlighting, thanks to the

413 threshold value, a chemical pressure not identified by the ROCCH observations.

414 Finally, the proposed methodology seems to be relevant to diagnose finely and robustly abnormal levels of

415 sperm DNA damage in P. serratus and consequently to characterize the genotoxic quality of water bodies along

416 the shoreline. However, it could be interesting to improve the ecological relevance of this tool to study the

417 impact of sperm DNA damage on parameters of reproductive and recruitment success (e.g. fertilization and

418 hatching success; abnormality rate during the early and late phases of embryo-larval development). So, the

419 abnormal sperm DNA damage could be interpreted relative to the potential risk incurred for the populations. In

420 this way, several authors have demonstrated, in laboratory in vivo and ex vivo exposures of semen, a significant

421 relationship between sperm DNA damage and progeny defects in fish species (Devaux et al. 2011, Santos et al.

422 2013) as well as in invertebrate species (Lacaze et al. 2011b; Lewis \& Galloway, 2009). More recently, Devaux 
et al. (2015) have reported such relationships in the fish nase (i.e. Chondrostoma nasus) sampled in a heavily contaminated station, suggesting that levels of DNA damage sufficient to lead to a fitness impairment could be found in a realistic environmental scenario. However, a transversal reading of the whole of these works tends to show that the level of sperm DNA damage required to cause significant alterations of reproductive success are dependent on the studied species and/or the considered endpoint. Consequently, it is difficult to replace the high levels of sperm DNA damage measured during the present study within the Southern Antifer, Octeville and Cap de la Hève populations with respect to the reproduction and progeny risks for prawns, simply on the basis of the literature analysis. Future work is thus needed to investigate this link in palaemonid prawns.

\section{Conclusion}

433 The aim of this study was to assess the natural variability of DNA damage on $P$. serratus spermatozoa in order to determine a baseline level. The results showed that DNA damage on spermatozoa of $P$. serratus are not related to intrinsic biotic factors (i.e. total size; total weight; molting stage) and to environmental factors (i.e. the water temperature) obtained with monthly sampling in 2015-2016 at Yport. We have proposed a baseline level and maximum threshold beyond which the increase of DNA damage may be attributed to present or past contamination exposure and so significant differences between sites could be easily reported. Finally, the biological data and the reference distribution appear to make it possible to discriminate between the sites according to the pressure/contamination gradient of the Seine Bay.

\section{Acknowledgments}

443 This study was supported by project ECOTONES funded by the program Seine-Aval V (Public Interest Groups Seine-Aval), the Research Federation CNRS 3730 SCALE and the Normandie Region. The authors also thank

Mrs. D. Hallidy for proof-reading the English.

\section{References}

Aitken, R.J., Baker, M.A., 2006. Oxidative stress, sperm survival and fertility control. Mol. Cell. Endocrinol. 250, 66-69.

Aitken, R.J., De Iuliis, G.N., 2007. Origins and consequences of DNA damage in male germ cells. Reprod. Biomed. Online 14, 727-733.

Aitken, R.J., Koopman, P., Lewis, S.E.M., 2004. Seeds of concern. Nat. news 432, 48-52.

Akcha, F., Leday, G., Pfohl-Leszkowicz, A., 2004. Measurement of DNA adducts and strand breaks in dab (Limanda limanda) collected in the field: Effects of biotic (age, sex) and abiotic (sampling site and period) factors on the extent of DNA damage. Mutat. Res. - Fundam. Mol. Mech. Mutagen. 552, 197-207.

Akcha, F., Vincent Hubert, F., Pfhol-Leszkowicz, A., 2003. Potential value of the comet assay and DNA adduct measurement in dab (Limanda limanda) for assessment of in situ exposure to genotoxic compounds. 
Mutat. Res. - Genet. Toxicol. Environ. Mutagen. 534, 21-32.

Amiard-Triquet, C., Amiard, J. C., \& Mouneyrac, C. (Eds.). 2015. Aquatic ecotoxicology: advancing tools for dealing with emerging risks. Academic Press.

Anderson, G., 1985. Species Profiles. Life Histories and Environmental Requirements of Coastal Fishes and Invertebrates (Gulf of Mexico). GRASS SHRIMP. US Fish Wild Serv Biol Rep 82, 11-35.

Augris, C., 2004. Evolution morpho-sédimentaire du domaine littoral et marin de la Seine-Maritime. Editions Quae.

Azqueta, A., Collins, A.R., 2013. The essential comet assay: A comprehensive guide to measuring DNA damage and repair. Arch. Toxicol. 87, 949-968.

Azqueta, A., Meier, S., Priestley, C., Gutzkow, K.B., Brunborg, G., Sallette, J., Soussaline, F., Collins, A., 2011. The influence of scoring method on variability in results obtained with the comet assay. Mutagenesis 26, 393-399.

Barrick, A., Châtel, A., Marion, J.M., Perrein-Ettajani, H., Bruneau, M., Mouneyrac, C., 2016. A novel methodology for the determination of biomarker baseline levels in the marine polychaete Hediste diversicolor. Mar. Pollut. Bull. 1, 275-280.

Bocquene, G., Bellanger, C., Cadiou, Y., Galgani, F., 1995. Joint action of combinations of pollutants on the acetylcholinesterase activity of several marine species. Ecotoxicology 4, 266-279.

Bolognesi, C., Frenzilli, G., Lasagna, C., Perrone, E., Roggieri, P., 2004. Genotoxicity biomarkers in Mytilus galloprovincialis: Wild versus caged mussels. Mutat. Res. - Fundam. Mol. Mech. Mutagen. 552, $153-162$.

Brivois, O., Desmazes, F., Müller, H., 2015. Tests méthodologiques pour l'évaluation des impacts hydromorphologiques d'aménagements côtiers en Seine - Normandie dans le cadre de la DCE.

Buschini, A., Carboni, P., Martino, A., Poli, P., Rossi, C., 2003. Effects of temperature on baseline and genotoxicant-induced DNA damage in haemocytes of Dreissena polymorpha. Mutat. Res. - Genet. Toxicol. Environ. Mutagen. 537, 81-92.

Campillo, A., 1975. Contribution a l'etude de l'elevage de la crevette rose Palaemon serratus (Pennant) en captivité. Rev. Trav. Inst. Pêches marit. 39, 381-393.

Claxton, L.D., Houk, V.S., Hughes, T.J., 1998. Genotoxicity of industrial wastes and effluents. Mutat. Res. Rev. Mutat. Res. 410, 237-243.

Collins, A.R., 2004. The comet assay for DNA damage and repair: principles, applications, and limitations. Mol. Biotechnol. 26, 249-261.

Cotelle, S., Fe, J.F., 1999. Review Comet Assay in Genetic Ecotoxicology : A Review 255, 246-255.

Coulaud, R., Geffard, O., Xuereb, B., Lacaze, E., Quéau, H., Garric, J., Charles, S., Chaumot, A., 2011. In situ feeding assay with Gammarus fossarum (Crustacea): Modelling the influence of confounding factors to improve water quality biomonitoring. Water Res. 45, 6417-6429.

De Andrade, V.M., De Freitas, T.R.O., Da Silva, J., 2004. Comet assay using mullet (Mugil sp.) and sea catfish (Netuma sp.) erythrocytes for the detection of genotoxic pollutants in aquatic environment. Mutat. Res. Genet. Toxicol. Environ. Mutagen. 560, 57-67.

Devaux, A., Fiat, L., Gillet, C., \& Bony, S., 2011. Reproduction impairment following paternal genotoxin exposure in brown trout (Salmo trutta) and Arctic charr (Salvelinus alpinus). Aquatic toxicology, 101(2), 405-411.

Devaux, A., Bony, S., Plenet, S., Sagnes, P., Segura, S., Suaire, R., M., Novak, A., Gilles \& Olivier, J. M., 2015. Field evidence of reproduction impairment through sperm DNA damage in the fish nase (Chondrostoma nasus) in anthropized hydrosystems. Aquatic Toxicology, 169, 113-122.

Dévier, M.H., Le Dû-Lacoste, M., Akcha, F., Morin, B., Peluhet, L., Le Menach, K., Burgeot, T., Budzinski, H., 2013. Biliary PAH metabolites, EROD activity and DNA damage in dab (Limanda limanda) from Seine Estuary (France). Environ. Sci. Pollut. Res. 20, 708-722.

Dixon, D.R., Pruski, A.M., Dixon, L.R.J., Jha, A.N., 2002. Marine invertebrate eco-genotoxicology: a methodological overview. Mutagenesis 17, 495-507.

Drach, P., 1944. Etude préliminaire sur le cycle d'intermue et son conditionnement hormonal chez Leander serratus (Pennant). Bull. biol. Fr. belg, 78, 40-62.

Erraud, A., Bonnard, M., Duflot, A., Geffard, A., Danger, J.-M., Forget-Leray, J., Xuereb, B., 2017. Assessment of sperm quality in palaemonid prawns using Comet assay: methodological optimization. Environ. Sci. Pollut. Res.

Flammarion, P., Devaux, a, Nehls, S., Migeon, B., Noury, P., Garric, J., 2002. Multibiomarker responses in fish from the Moselle River (France). Ecotoxicol. Environ. Saf. 51, 145-153.

Flammarion, P., Garric, J., 1997. Cyprinids EROD activities in low contaminated rivers : A relevant statistical approach to estimate reference levels for EROD biomarker? Chemosphere 35, 2375-2388.

Frasco, M.F., Fournier, D., Carvalho, F., Guilhermino, L., 2008. Does mercury interact with the inhibitory effect of dichlorvos on Palaemon serratus (Crustacea: Decapoda) cholinesterase? Sci. Total Environ. 404, 88-93.

Frenzilli, G., Nigro, M., Lyons, B.P., 2009. The Comet assay for the evaluation of genotoxic impact in aquatic 
environments. Mutat. Res. - Rev. Mutat. Res. 681, 80-92.

Frenzilli, G., Nigro, M., Scarcelli, V., Gorbi, S., Regoli, F., 2001. DNA integrity and total oxyradical scavenging capacity in the Mediterranean mussel, Mytilus gallopro 6 incialis : a field study in a highly eutrophicated coastal lagoon 53, 19-32.

Hagger, J.A., Jones, M.B., Lowe, D., Leonard, D.R.P., Owen, R., Galloway, T.S., 2008. Application of biomarkers for improving risk assessments of chemicals under the Water Framework Directive: A case study. Mar. Pollut. Bull. 56, 1111-1118.

Hanson, N., 2011. Using biological data from field studies with multiple reference sites as a basis for environmental management: The risks for false positives and false negatives. J. Environ. Manage. 92, 610619.

Hanson, N., Förlin, L., Larsson, A., 2010. Spatial and annual variation to define the normal range of biological endpoints: An example with biomarkers in perch. Environ. Toxicol. Chem. 29, 2616-2624.

Jemec, A., Drobne, D., Tišler, T., Sepčić, K., 2010. Biochemical biomarkers in environmental studies-lessons learnt from enzymes catalase, glutathione S-transferase and cholinesterase in two crustacean species. Environ. Sci. Pollut. Res. 17, 571-581.

Jha, A.N., 2008. Ecotoxicological applications and significance of the comet assay. Mutagenesis 23, $207-221$.

Jubeaux, G., Simon, R., Salvador, A., Lopes, C., Lacaze, E., Quéau, H., Chaumot, A., Geffard, O., 2012. Vitellogenin-like protein measurement in caged Gammarus fossarum males as a biomarker of endocrine disruptor exposure: inconclusive experience. Aquat. Toxicol. 122-123, 9-18.

Key, P.B., Wirth, E.F., Fulton, M.H., 2006. A Review of Grass Shrimp, Palaemonetes spp., as a Bioindicator of Anthropogenic Impacts. Environ. Bioindic. 1, 115-128.

Lacaze, E., Devaux, A., Jubeaux, G., Mons, R., Gardette, M., Bony, S., Garric, J., Geffard, O., 2011. DNA damage in Gammarus fossarum sperm as a biomarker of genotoxic pressure: intrinsic variability and reference level. Sci. Total Environ. 409, 3230-6.

Lacaze, E., Geffard, O., Goyet, D., Bony, S., \& Devaux, A., 2011. Linking genotoxic responses in Gammarus fossarum germ cells with reproduction impairment, using the Comet assay. Environmental research, $111(5), 626-634$.

Lacaze, E., Geffard, O., Bony, S., Devaux, A., 2010. Genotoxicity assessment in the amphipod Gammarus fossarum by use of the alkaline Comet assay. Mutat. Res. 700, 32-8.

Lee, R.F., Steinert, S., 2003. Use of the single cell gel electrophoresis/comet assay for detecting DNA damage in aquatic (marine and freshwater) animals. Mutat. Res. - Rev. Mutat. Res. 544, 43-64.

Leinio, S., Lehtonen, K.K., 2005. Seasonal variability in biomarkers in the bivalves Mytilus edulis and Macoma balthica from the northern Baltic Sea. Comp. Biochem. Physiol. - C Toxicol. Pharmacol. 140, 408-421.

Lewis, C., Galloway, T., 2009. Reproductive Consequences of Paternal Genotoxin Exposure in Marine Invertebrates. Environ. Sci. Technol. 43, 928-933.

McCarthy, J. F., \& Shugart, L. R., 1990. Biomarkers of environmental contamination.

Magni, P., De Falco, G., Falugi, C., Franzoni, M., Monteverde, M., Perrone, E., Sgro, M., Bolognesi, C., 2006. Genotoxicity biomarkers and acetylcholinesterase activity in natural populations of Mytilus galloprovincialis along a pollution gradient in the Gulf of Oristano (Sardinia, western Mediterranean). Environ. Pollut. 142, 65-72.

Martins, M., Costa, P.M., 2015. The comet assay in Environmental Risk Assessment of marine pollutants: Applications, assets and handicaps of surveying genotoxicity in non-model organisms. Mutagenesis 30 , 89-106.

Michel, C., Bourgeault, A., Gourlay-Francé, C., Palais, F., Geffard, A., Vincent-Hubert, F., 2013. Seasonal and PAH impact on DNA strand-break levels in gills of transplanted zebra mussels. Ecotoxicol. Environ. Saf. 92, 18-26.

Mitchelmore, C.L., Chipman, J.K., 1998. DNA strand breakage in aquatic organisms and the potential value of the comet assay in environmental monitoring. Mutat. Res. - Fundam. Mol. Mech. Mutagen. 399, $135-147$.

Monfort, P., Le Bec, C., 2011. Qualité du Milieu Marin Littoral - Bulletin de la surveillance - Edition 201183.

Oliveira, M., Maria, V.L., Ahmad, I., Pacheco, M., Santos, M.A., 2010. Seasonal Liza aurata tissue-specific DNA integrity in a multi-contaminated coastal lagoon (Ria de Aveiro, Portugal). Mar. Pollut. Bull. 60, 1755-1761.

Pain-devin, S., Cossu-leguille, C., Geffard, A., Giambérini, L., Jouenne, T., Minguez, L., 2014. Towards a better understanding of biomarker response in field survey: A case study in eight populations of zebra mussels $155,52-61$.

Parnes, S., Raviv, S., Shechter, A., \& Sagi, A., 2006. Males also have their time of the month! Cyclic disposal of old spermatophores, timed by the molt cycle, in a marine shrimp. Journal of experimental biology, 209(24), 4974-4983.

Pfeifer, S., Schiedek, D., Dippner, J.W., 2005. Effect of temperature and salinity on acetylcholinesterase activity, a common pollution biomarker, in Mytilus sp. from the south-western Baltic Sea. J. Exp. Mar. Bio. Ecol. 
320, 93-103.

Pisanelli, B., Benedetti, M., Fattorini, D., Regoli, F., 2009. Seasonal and inter-annual variability of DNA integrity in mussels Mytilus galloprovincialis: A possible role for natural fluctuations of trace metal concentrations and oxidative biomarkers. Chemosphere 77, 1551-1557.

Rank, J., Jensen, K., Jespersen, P.H., 2005. Monitoring DNA damage in indigenous blue mussels (Mytilus edulis) sampled from coastal sites in Denmark. Mutat. Res. - Genet. Toxicol. Environ. Mutagen. 585, 3342.

Richard, P., 1978. Influence de la température sur la croissance et la mue de Palaemon serratus en fonction de leur taille. Aquaculture 14, 13-22.

Rioult, D., Pasquier, J., Boulangé-Lecomte, C., Poret, A., Abbas, I., Marin, M., Minier, C., Le Foll, F., 2014. The multi-xenobiotic resistance (MXR) efflux activity in hemocytes of Mytilus edulis is mediated by an ATP binding cassette transporter of class $\mathrm{C}$ (ABCC) principally inducible in eosinophilic granulocytes. Aquat. Toxicol. 153, 98-109.

Sanchez, W., Piccini, B., Ditche, J.M., Porcher, J.M., 2008. Assessment of seasonal variability of biomarkers in three-spined stickleback (Gasterosteus aculeatus L.) from a low contaminated stream: Implication for environmental biomonitoring. Environ. Int. 34, 791-798.

Santos, R., Palos-Ladeiro, M., Besnard, A., Porcher, J. M., Bony, S., Sanchez, W., \& Devaux, A., 2013. Relationship between DNA damage in sperm after ex vivo exposure and abnormal embryo development in the progeny of the three-spined stickleback. Reproductive Toxicology, 36, 6-11.

Santos, R., Palos-Ladeiro, M., Besnard, A., Reggio, J., Vulliet, E., Porcher, J. M., ... \& Devaux, A., 2013. Parental exposure to methyl methane sulfonate of three-spined stickleback: contribution of DNA damage in male and female germ cells to further development impairment in progeny. Ecotoxicology, 22(5), 815824.

Santos, R., Palos Ladeiro, M., Besnard, A., Vulliet, E., Porchet, J.M., Bony, S., Devaux, A., Sanchez, W., 2014. Kinetic response of a genotoxicity biomarker in the three-spined stickleback and implication for environmental monitoring. Ecotoxicol. Environ. Saf. 102, 6-11.

Shaw, J.P., Large, A.T., Chipman, J.K., Livingstone, D.R., Peters, L.D., 2000. Seasonal variation in mussel Mytilus edulis digestive gland cytochrome P4501A- and 2E-immunoidentified protein levels and DNA strand breaks (Comet assay). Mar. Environ. Res. 50, 405-409.

Sheehan, D., Power, A., 1999. Effects of seasonality on xenobiotic and antioxidant defence mechanisms of bivalve molluscs. Comp. Biochem. Physiol. - C Pharmacol. Toxicol. Endocrinol. 123, 193-199.

Speit, G., Vasquez, M., Hartmann, A., 2009. The comet assay as an indicator test for germ cell genotoxicity. Mutat. Res. - Rev. Mutat. Res. 681, 3-12.

Tappin, A.D., Millward, G.E., 2015. The English Channel: Contamination status of its transitional and coastal waters. Mar. Pollut. Bull. 95, 529-550.

Underwood, A.J., 2000. Experimental ecology of rocky intertidal habitats: What are we learning? J. Exp. Mar. Bio. Ecol. 250, 51-76.

Villani, P., Eleuteri, P., Grollino, M.G., Rescia, M., Altavista, P., Spanò, M., Pacchierotti, F., Cordelli, E., 2010. Sperm DNA fragmentation induced by DNAse I and hydrogen peroxide: An in vitro comparative study among different mammalian species. Reproduction 140, 445-452.

Wiklund, A.K.E., Sundelin, B., 2004. Biomarker sensitivity to temperature and hypoxia - A seven year field study. Mar. Ecol. Prog. Ser. 274, 209-214.

Wirzinger, G., Weltje, L., Gercken, J., Sordyl, H., 2007. Genotoxic damage in field-collected three-spined sticklebacks (Gasterosteus aculeatus L.): A suitable biomonitoring tool? Mutat. Res. - Genet. Toxicol. Environ. Mutagen. 628, 19-30.

Xuereb, B., Chaumot, A., Mons, R., Garric, J., Geffard, O., 2009. Acetylcholinesterase activity in Gammarus fossarum (Crustacea Amphipoda). Intrinsic variability, reference levels, and a reliable tool for field surveys. Aquat. Toxicol. 93, 225-233.

Table 1. Annual means ( $\mathrm{n}=2$ analyses per year) of cumulated concentrations of 12 PAHs, 9 PCBs and 7 metals measured in mussel soft-tissues (Mytilus edulis) from six sampling sites (i.e. Yport; Southern Antifer; Cap de la Hève; Villerville; Ouistreham and Port-en-Bessin). These data were generated by the French marine environment monitoring network (ROCCH; "http://www.ifremer.fr/envlit/". PCBs and PAHs concentrations are expressed in $\mu \mathrm{g} / \mathrm{kg}$-dry weight and metals concentrations in $\mathrm{mg} / \mathrm{kg}$-dry weight. A contamination index was proposed for each station on the basis of a rank transformation (see section 2.4) 
636

637

638

639

640

641

642

643

644

645

646

647

648

649

650

651

652

653

654

655

656

657

658

659

660

661

662

663

664

665

666

667

668

669

670

671

672

673

674

675

676

Figure 1. Localization of the sampling stations along the Seine Bay (Normandy; France). White point surround of black = stations of biomonitoring without $\mathrm{ROCCH}$ data; white point surround of red $=$ stations of biomonitoring with $\mathrm{ROCCH}$ data; red point surrounded of black $=\mathrm{ROCCH}$ data without sampling.

Figure 2. Observation of the setogenesis morphological changes during the molt cycle from A to D2 (x 100 and $\mathrm{x}$ 400) : Stage A (early postmolt): the setal lumen filled with setal matrix; Stage B (late post molt): retraction of the satal matrix and the beginning to internal cone formation; Stage C (intermolt): empty setal lumen and internal cone; Stage D0 (onset of premolt): separation of the cuticle and epidermis; Stage D1' (early premolt): formation of a circular fold around the nervous cluster of sethae; Stage D1',(intermediate premolt): the circular fold reaches its maximum depth beginning of secretion; Stage D1"' (late premolt): the walls of the fold secrete the skeletal case; Stage D2 (late premolt): formation of the preexuvial wall of the future skeletal.

Figure 3. Visual classification of DAPI-stained Comet figures in Palaemon serratus spermatozoa (class 0 to 4 ) adapted from Collins (2004): class 0, no damage; class 1, low damages; class 2, medium damages; class 3, high damages; class 4, complete damage.

Figure 4. Natural variability of DNA damage (expressed in arbitrary units AU) measured in Palaemon serratus spermatozoa during its period of attendance on the coast from May to November 2015-2016 at Yport (reference site). Results are shown in boxplot (i.e. the median, the first and the third quartiles, the non-outliers range and the outliers). The mean (red point) was added to boxplots to provide as much information as possible of data set. White boxplots $=2015$, grey boxplots $=2016$; continuous line represents the bi-annual mean of DNA damage; the dashed lines represent the $95 \%$ unilateral confidence intervals $(n=10)$.

Figure 5. Relationship between the temperature (A), the total cephalothoracic length (B) or the total weight (C) and DNA damage of spermatozoa from males $P$. serratus sampled in Yport from May to November 2015-2016 $(n=130)$.

Figure 6. Relationship between the molting stage and DNA damage of spermatozoa from $P$. serratus sampled in Yport from May to November 2015-2016 (n=130).

Figure 7. Sperm DNA damage measured in field populations of Palaemon serratus from different stations along the Seine Bay sampled on 7-10 sites of the Seine estuary and the bay of Seine during autumn 2015-2016. $(n=10)$ Results are shown in boxplot (i.e. the median, the first and the third quartiles, the non-outliers range and the outliers). The mean (red point) was added to boxplots to provide as much information as possible of data set. White boxplots $=2015$, grey boxplots $=2016$; continuous line represents the bi-annual mean of DNA damage at Yport; the dashed lines represent the $95 \%$ unilateral confidence intervals $(n=10)$. Stations are presented from the North to the South of the Seine bay and the Antifer seawall and the Seine estuary are replaced with vertical dashed lines. 
Table 1 :

\begin{tabular}{|c|c|c|c|c|c|c|c|}
\hline \multirow[b]{3}{*}{ Mussels sampling sites } & \multicolumn{2}{|c|}{ PCBs } & \multicolumn{2}{|c|}{ PAHs } & \multicolumn{2}{|c|}{ Metals } & \multirow[b]{3}{*}{ Contamination index } \\
\hline & \multicolumn{2}{|c|}{$\mu g / k g-d r y$ weight } & \multicolumn{2}{|c|}{$\mu g / k g$-dry weight } & \multicolumn{2}{|c|}{$\mathrm{mg} / \mathrm{kg}$-dry weight } & \\
\hline & 2015 & 2016 & 2015 & 2016 & 2015 & 2016 & \\
\hline Yport & 137.2 & / & (mean & 2014) & 72.7 & 102.9 & 1.8 \\
\hline Antifer south & 293.7 & 357.7 & 67.6 & 233.0 & 176.9 & 140.5 & 3.2 \\
\hline Cap de la Hève & 455.9 & 541.9 & 373.4 & 620.3 & 337.8 & 174.5 & 6 \\
\hline $\begin{array}{l}\text { Villerville-sur-mer } \\
\text { (Trouville-sur-mer) }\end{array}$ & 401.9 & 488.0 & 195.8 & 213.0 & 293.3 & 132.1 & 4.3 \\
\hline $\begin{array}{l}\text { Ouistreham } \\
\text { (Ver-sur-mer) }\end{array}$ & 166.6 & 189.1 & 137.5 & 121.4 & 242.43 & 86.4 & 2.4 \\
\hline $\begin{array}{l}\text { Port-en-bessin } \\
\text { (Longues-sur-mer) }\end{array}$ & 75.7 & 77.2 & 78.4 & 65.7 & 259.7 & 112.4 & 2.0 \\
\hline
\end{tabular}


Figure 1.
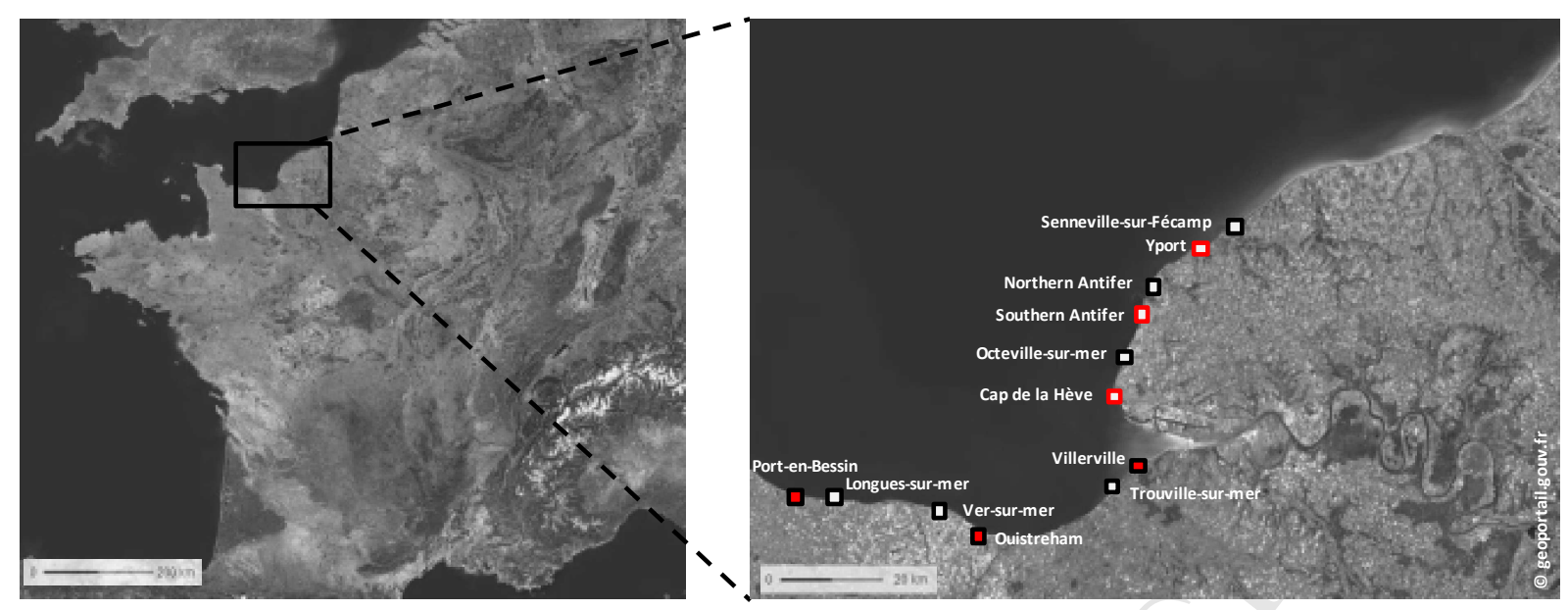
Figure 2.
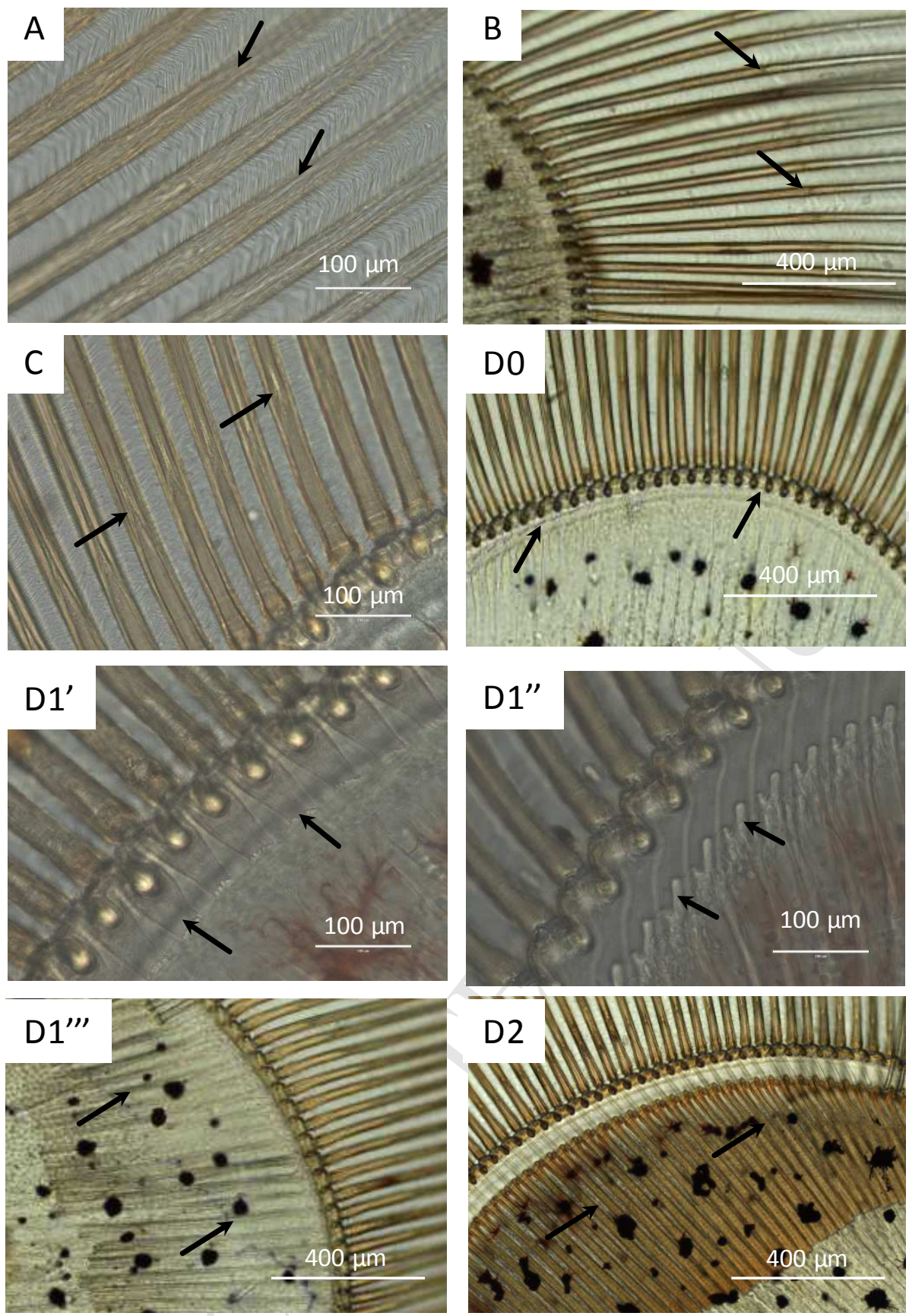
Figure 3

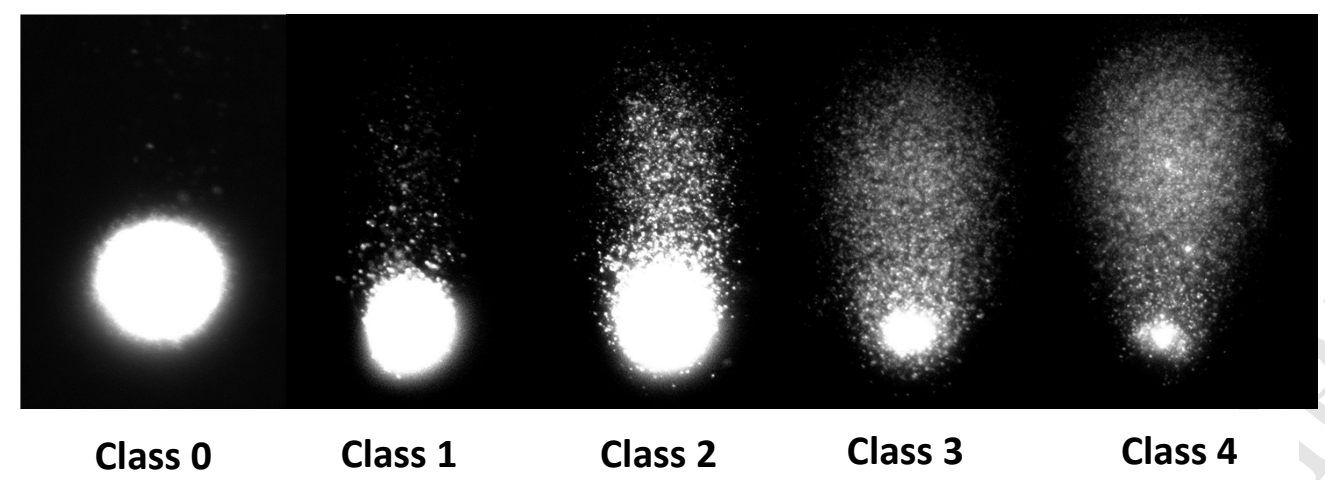


Figure 4.

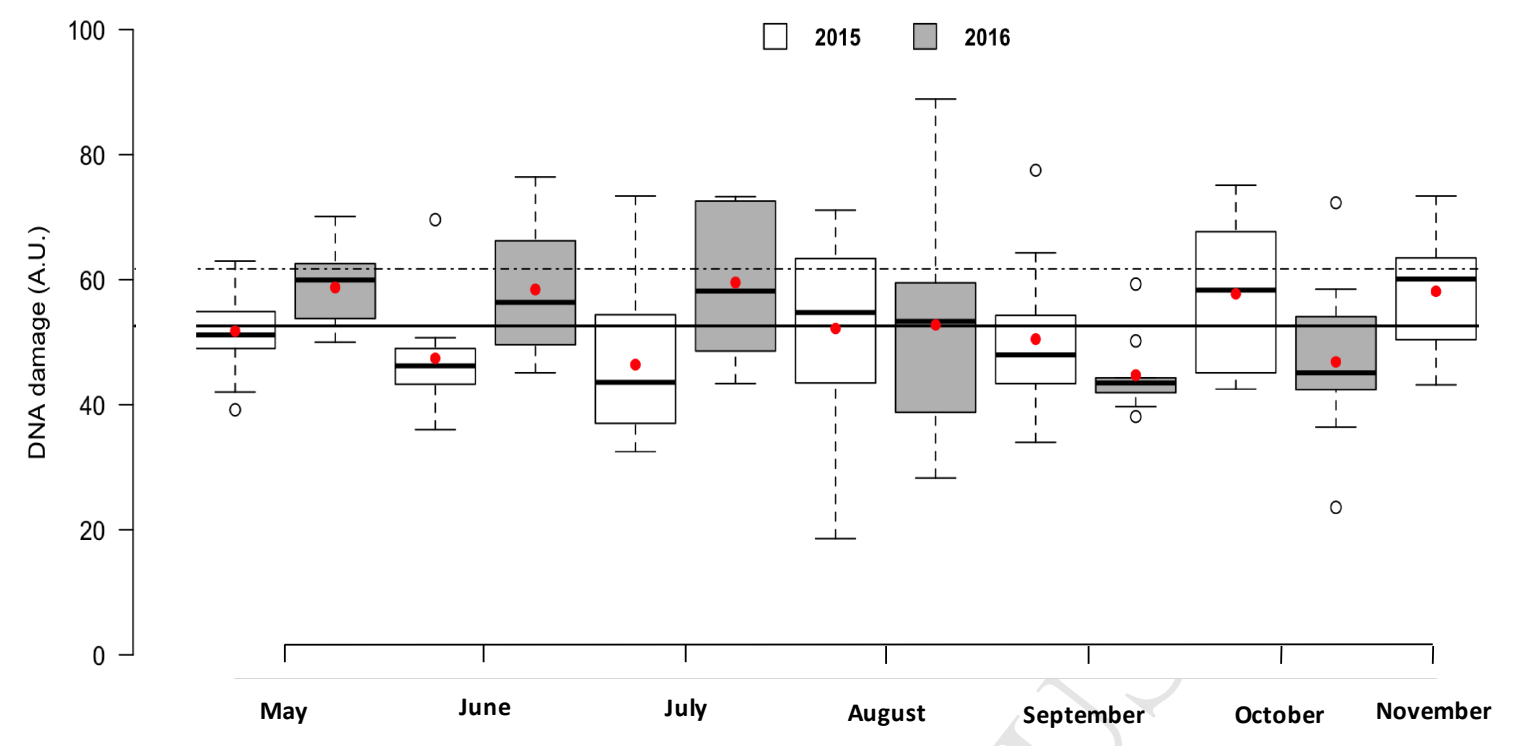


Figure 5.
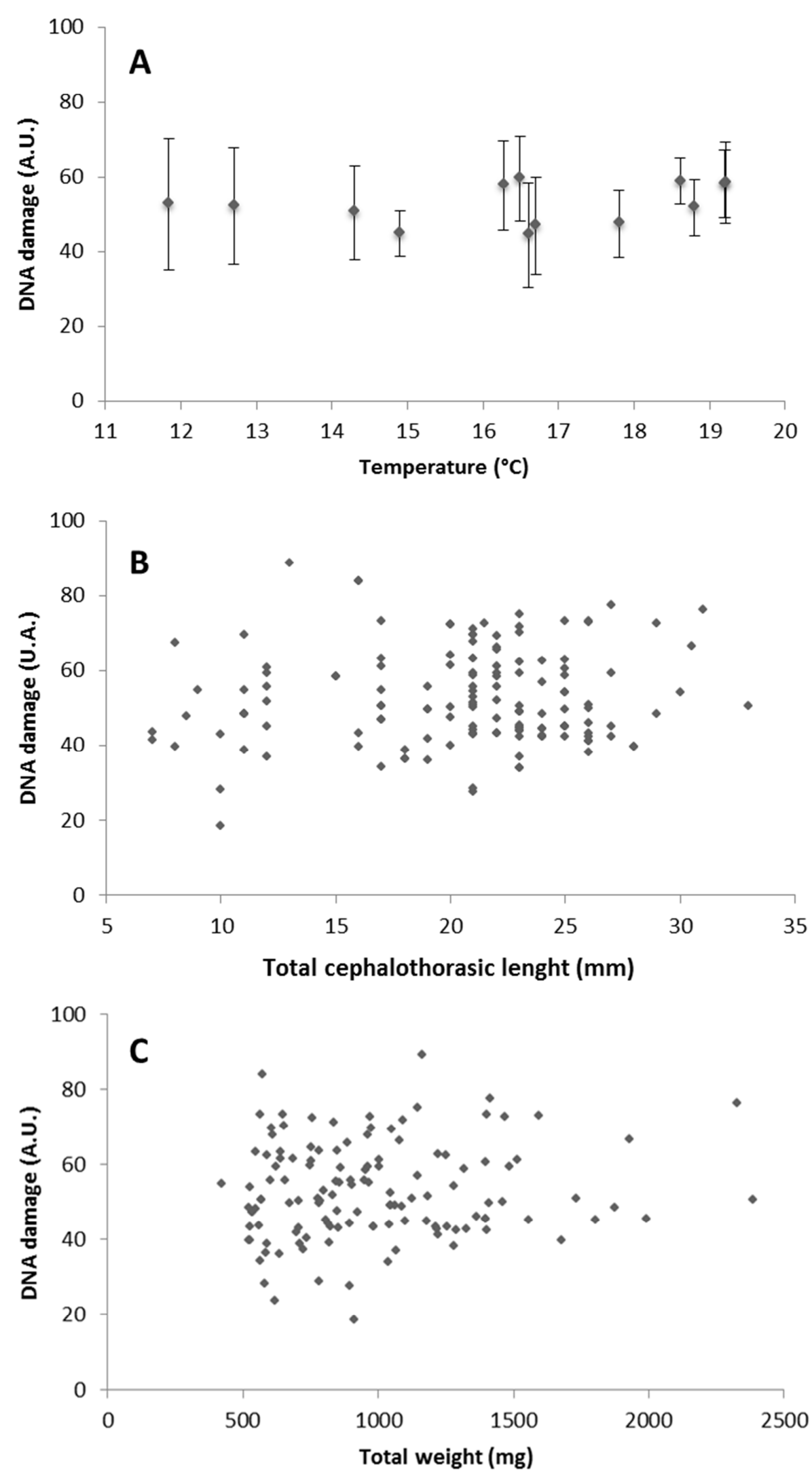
Figure 6.

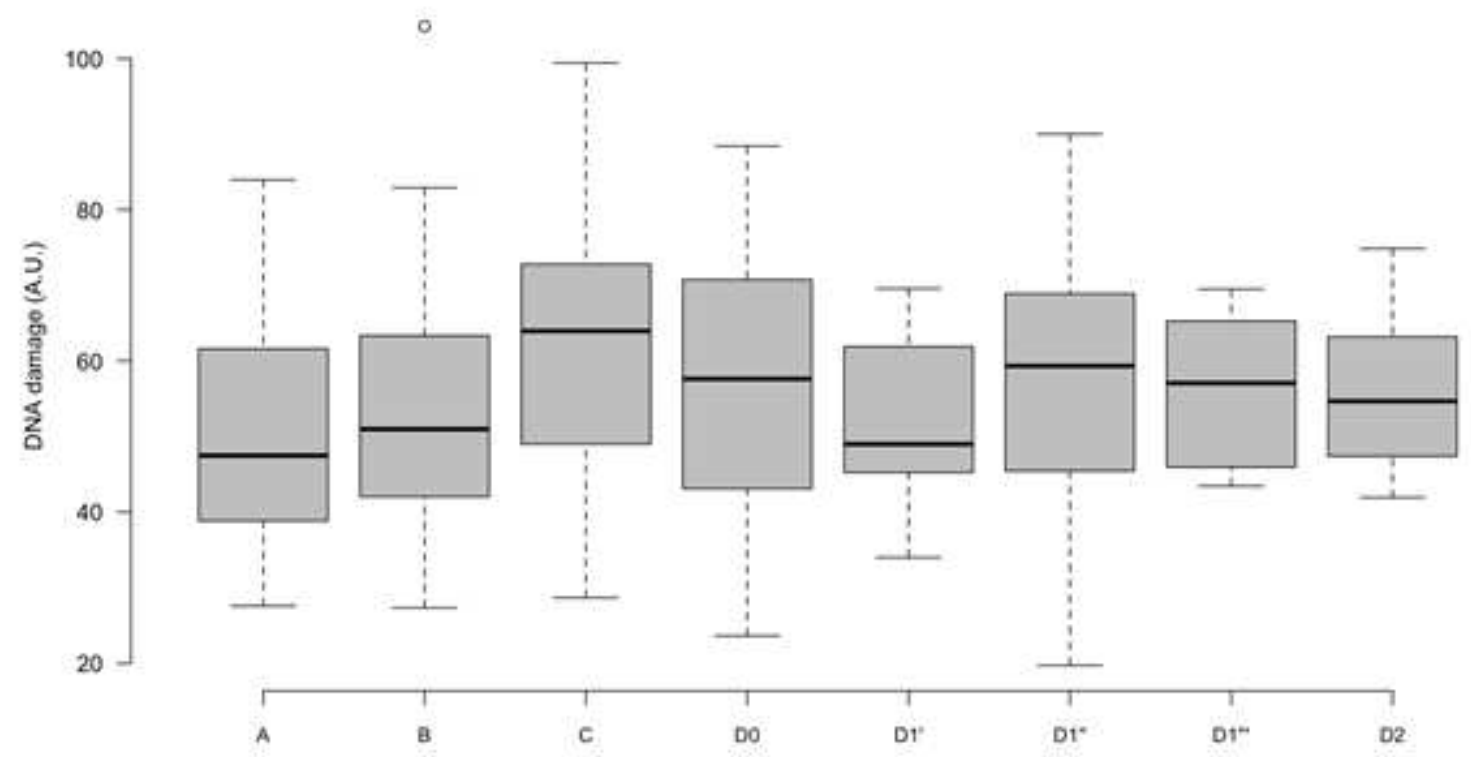


Figure 7.

$\square \quad 2015 \quad \square \quad 2016$

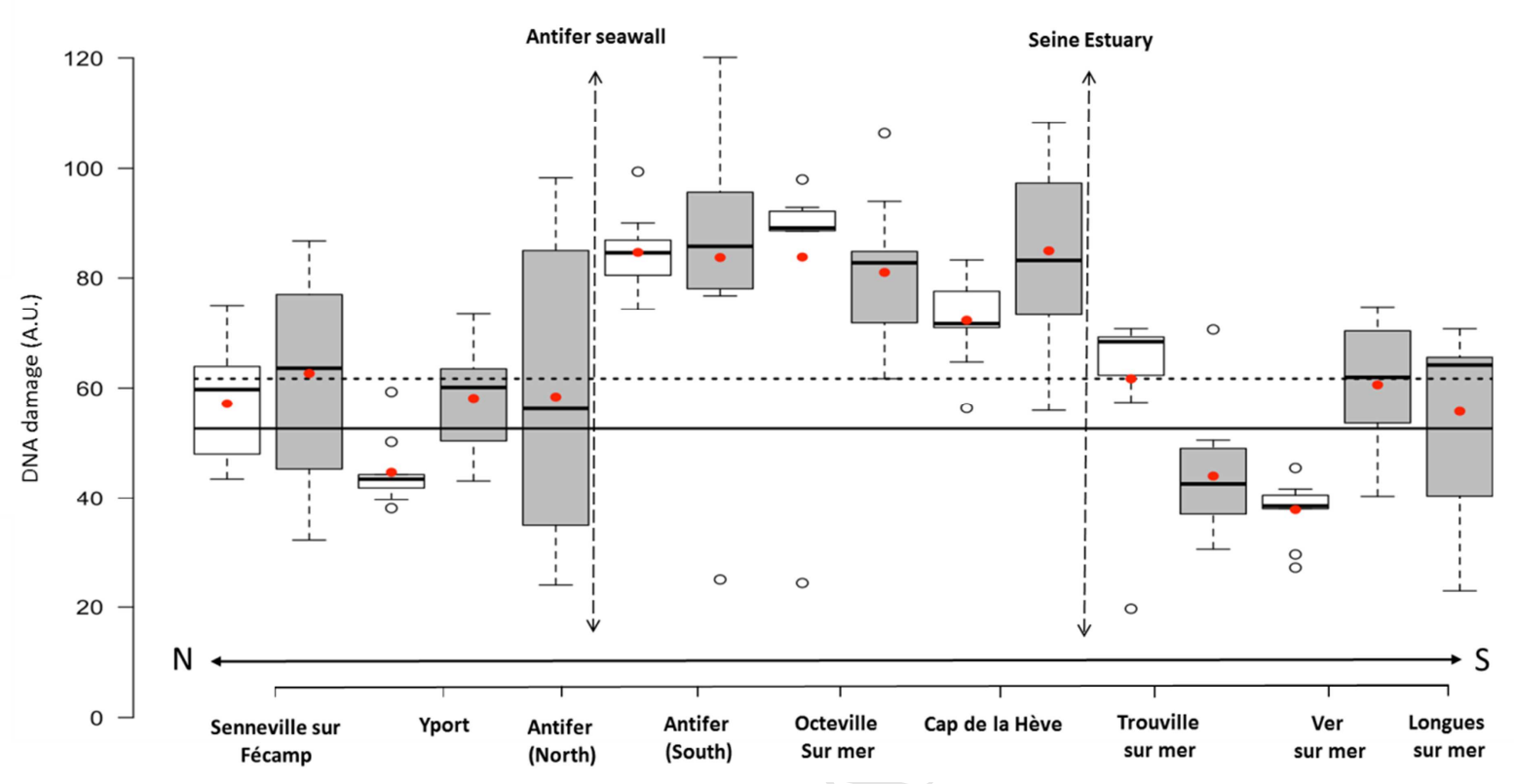




\section{Highlights}

- We propose a reference distribution for sperm DNA integrity in Palaemon serratus

- The influence of main confounding factors on sperm DNA integrity was quantified

- Our reference distribution proved to be robust to environmental conditions

- Contamination impacts can be reveal by this biomarker to assess water quality 